\title{
Analysis and Design of Bi-Directional DC-DC Converter in the Extended Run Time DC UPS System Based on Fuel Cell and Supercapacitor
}

Zhang, Zhe; Thomsen, Ole Cornelius; Andersen, Michael A. E.; Schmidt, Jacob D.; Nielsen, Henning R.

Published in:

Twenty-Fourth Annual IEEE Applied Power Electronics Conference and Exposition, 2009. APEC 2009

Link to article, DOI:

10.1109/APEC.2009.4802739

Publication date:

2009

Document Version

Publisher's PDF, also known as Version of record

Link back to DTU Orbit

Citation (APA):

Zhang, Z., Thomsen, O. C., Andersen, M. A. E., Schmidt, J. D., \& Nielsen, H. R. (2009). Analysis and Design of Bi-Directional DC-DC Converter in the Extended Run Time DC UPS System Based on Fuel Cell and Supercapacitor. In Twenty-Fourth Annual IEEE Applied Power Electronics Conference and Exposition, 2009. APEC 2009 (pp. 714-719). IEEE. https://doi.org/10.1109/APEC.2009.4802739

\section{General rights}

Copyright and moral rights for the publications made accessible in the public portal are retained by the authors and/or other copyright owners and it is a condition of accessing publications that users recognise and abide by the legal requirements associated with these rights.

- Users may download and print one copy of any publication from the public portal for the purpose of private study or research.

- You may not further distribute the material or use it for any profit-making activity or commercial gain

- You may freely distribute the URL identifying the publication in the public portal 


\title{
Analysis and Design of Bi-directional DC-DC Converter in Extended Run Time DC UPS System Based on Fuel Cell and Supercapacitor
}

\author{
Zhe Zhang ${ }^{1}$, Ole C. Thomsen ${ }^{1}$, Michael A. E. Andersen ${ }^{1}$, Jacob D. Schmidt ${ }^{2}$ and Henning R. Nielsen ${ }^{2}$ \\ 1. Department of Electrical Engineering, Technical University of Denmark \\ Kgs. Lyngby 2800, Denmark \\ 2. APC Denmark ApS., Silcon Alle, Kolding, Denmark, DK-6000
}

\begin{abstract}
In this paper, an extended run time DC UPS system structure with fuel cell and supercapacitor is investigated. A wide input range bi-directional dc-dc converter is described along with the phase-shift modulation scheme and phase-shift with duty cycle control, in different modes. The delivered power and peak current are analyzed and calculated. The key parameters of the bi-directional dc-dc converter, the relationships between the input voltage, phase-shift angle, ratio of the transformer and leakage inductance are analyzed and optimized. Build the system mathematic model and a novel input voltage combined with load current feedback using PI controller with anti-windup scheme to realize closed-loop control of the whole system, and verify the feasibility of the control scheme proposed by simulation. A $1 \mathrm{~kW}$ prototype controlled by TMS320F2808 DSP is implemented and tested. Experimental results show the validity of design.
\end{abstract}

\section{INTRODUCTION}

Nowadays, with the growth of electric demand and the regulation of energy supply, the occurrence of outage is increasing in many countries. Extended run time UPS (Uninterruptible Power Supply) systems could be used to overcome these problems [1]. There are several ways of providing the extended run time, but most common solutions today are still the use of diesel generator and batteries. Comparing with diesel generators and batteries, fuel cells and supercapacitors hybrid UPS system can convert the chemical potential of the hydrogen into electric power directly, with consequent high conversion efficiency and possibility to obtain the extended range with the combustible feed from the outside [2]. During the fuel cell starting up or load requirement transient, the supercapacitor can be used as the buffering power source. The UPS block diagram researched in this paper is shown in Fig.1. We could find that the bidirectional DC-DC converter is to control the power flow from the energy sources and load and is key stage in the system. For high voltage ratio application, transformer coupled and isolated bi-directional DC converters have been proposed such as dual active bridge (DAB) [3], [4], [5] [6], dual active half bridge [7], [8], [9], full bridge current fed [10], [11] and their derivatives [12], [13], [14]. And the power flow could be controlled under the phase-shift modulation. To improve the system efficiency as well as increase the range of operation for the large-range-changeable input voltage, some

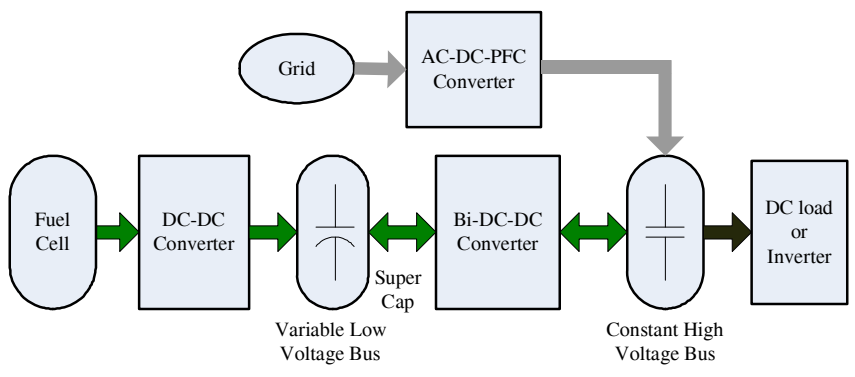

Figure 1. Block diagram of the whole system structure.

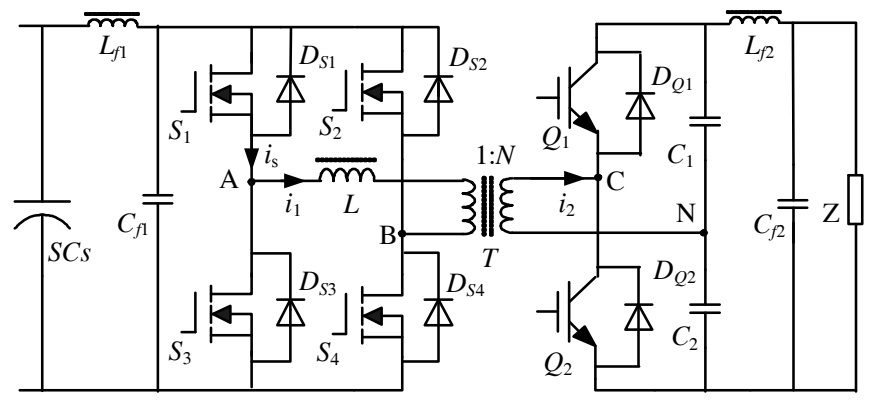

Figure 2. Voltage-fed full bridge with voltage doubler dc-dc converter

modulation schemes such as triangular modulation, trapezoidal modulation and PWM plus phase-shift modulation are investigated in [15], [16], [17] and [18], with adding the duty ratio as a modulated parameter.

In this paper, the voltage-fed full bridge with voltage doubler bi-directional dc-dc converter, shown in Fig. 2, with phase-shift modulation and phase-shift with duty cycle control is investigated. All the switches in the converter can implement turn-on under ZVS. Methods in choosing and designing circuit parameters such as leakage inductance, switching frequency and turn ratio to improve the efficiency and to increase the power range are discussed and hybrid modulation scheme for extended ZVS range and system startup method in section II. In section III, a novel load current feed back PI controller with anti-windup scheme are designed. Finally, in section IV, experimental results verify the effectiveness of the analysis and design. 

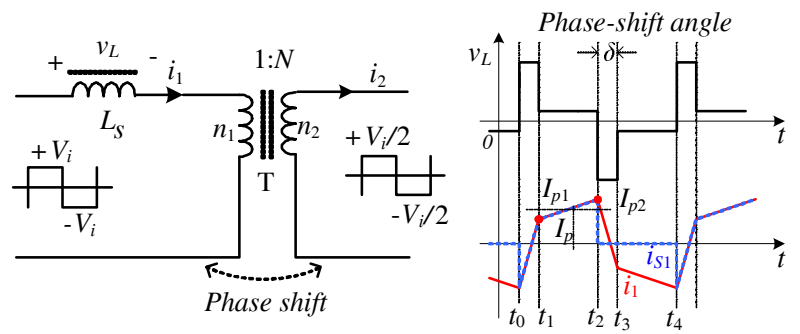

Figure 3. Simplified topology and theoretical waveforms

TABLE I

OPERATING PRINCIPLE

\begin{tabular}{|c|c|c|c|c|}
\hline \multirow{2}{*}{ Modes } & \multicolumn{2}{|c|}{ LV side } & \multicolumn{2}{c|}{ HV side } \\
\cline { 2 - 5 } & Gated & Conducting & Gated & Conducting \\
\hline$t_{0}<t<t_{1}$ & $\mathrm{~S}_{1}, \mathrm{~S}_{4}$ & $\mathrm{D}_{\mathrm{S} 1}, \mathrm{D}_{\mathrm{S} 4}$ & $\mathrm{Q}_{2}$ & $\mathrm{D}_{\mathrm{Q} 2}$ \\
\hline$t_{0}<t<t_{1}$ & $\mathrm{~S}_{1}, \mathrm{~S}_{4}$ & $\mathrm{~S}_{1}, \mathrm{~S}_{4}$ & $\mathrm{Q}_{2}$ & $\mathrm{Q}_{2}$ \\
\hline$t_{1}<t<t_{2}$ & $\mathrm{~S}_{1}, \mathrm{~S}_{4}$ & $\mathrm{~S}_{1}, \mathrm{~S}_{4}$ & $\mathrm{Q}_{1}$ & $\mathrm{D}_{\mathrm{Q} 1}$ \\
\hline$t_{2}<t<t_{3}$ & $\mathrm{~S}_{2}, \mathrm{~S}_{3}$ & $\mathrm{D}_{\mathrm{S} 2}, \mathrm{D}_{\mathrm{S} 3}$ & $\mathrm{Q}_{1}$ & $\mathrm{D}_{\mathrm{Q} 1}$ \\
\hline$t_{2}<t<t_{3}$ & $\mathrm{~S}_{2}, \mathrm{~S}_{3}$ & $\mathrm{~S}_{2}, \mathrm{~S}_{3}$ & $\mathrm{Q}_{1}$ & $\mathrm{Q}_{1}$ \\
\hline$t_{3}<t<t_{4}$ & $\mathrm{~S}_{2}, \mathrm{~S}_{3}$ & $\mathrm{~S}_{2}, \mathrm{~S}_{3}$ & $\mathrm{Q}_{2}$ & $\mathrm{D}_{\mathrm{Q} 2}$ \\
\hline
\end{tabular}

\section{BI-DIRECTIONAL CONVERTER}

\section{A. Stable operation mode}

When the fuel cell has been started up, the system works in the stable operation mode (Mode I) under $V_{i}=V_{o} / 2 N$. The gated and conducting switches during the various operating intervals of the bi-directional dc-dc converter shown in Fig. 2 are listed in the Table I. And the typical waveforms are shown in Fig. 3. During the interval $t_{0}<t<t_{1}$ and $t_{2}<t<t_{3}$ the resultant $\mathrm{mmf}$ exceeds the value needed to establish the rated core flux, unlike normal transformer operation, and the winding current changes rapidly and causes high RMS value.

With reference to Fig. 3, the current values as:

$$
\begin{gathered}
I_{p 1}=I_{p}-\Delta I_{p}=\frac{4 N V_{i} \delta+\left(V_{o}-2 N V_{i}\right) \pi}{4 \omega N L} . \\
I_{p 2}=I_{p}+\Delta I_{p}=\frac{2 V_{o} \delta+\left(2 N V_{i}-V_{o}\right) \pi}{4 \omega N L} . \\
\Delta I_{p}=\frac{I_{p 2}-I_{p 1}}{2}=\left(V_{i}-\frac{V_{o}}{2 N}\right) \frac{(\pi-\delta)}{2 \omega L} .
\end{gathered}
$$

where $V_{i}$ is voltage on the supercapacitor, $V_{o}$ is output voltage, $\omega$ is the switching angular frequency, $N$ is the turn ratio, $L$ is the sum of the transformer leakage inductance and that of the auxiliary inductor. It is evident that when the $\Delta I_{\mathrm{p}} \approx 0$, the current waveform is trapezoidal.

Under the condition that the primary impressed voltage is not equal to the secondary voltage referred to the primary caused by the load disturbance, the instantaneous inductor current, input voltage $v_{\mathrm{AB}}$ and the average power, $P_{\mathrm{AVG}}$ are given:

$$
\begin{aligned}
i(\delta, t)= & \sum_{n=1,}^{\infty} \frac{4}{n^{2}} \pi \omega L\left[\frac{V_{o}}{2 N} \cos n \delta-V_{i}\right] \cdot \cos n \omega t \\
& +\sum_{n=1,5, \ldots \ldots}^{\infty} \frac{2}{\pi \omega L N} \cdot V_{o} \cdot \sin n \delta \cdot \sin n \omega t .
\end{aligned}
$$
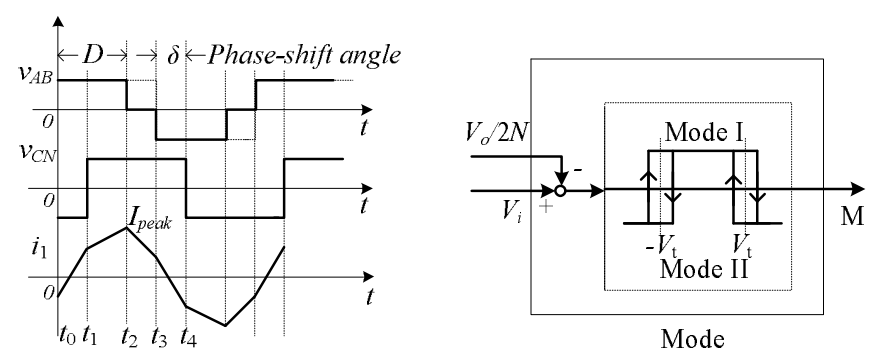

Figure 4. Theoretical waveforms in Mode I

Figure 5. Mode selection

$$
\begin{aligned}
v_{A B}(t) & =\sum_{A V G} \frac{4 V_{i}}{d} \cdot \sin n \omega t . \\
P_{A V G} & =\sum_{n=, 5, \ldots, \ldots} \frac{4 V_{i} \cdot V_{o}}{\pi^{2} \omega L N} \sin n \delta .
\end{aligned}
$$

Equation (4), (5) and (6) are very useful to analyze the harmonics in the system and extend the analysis results in [18], and then we can get the equivalent equation blow:

$$
P_{A V G}=P_{o}=I_{o} \cdot V_{o}=\frac{V_{i} \cdot V_{o} \cdot \delta \cdot(\pi-\delta)}{2 \pi \cdot \omega \cdot N \cdot L} .
$$

Under the constraint condition as:

$$
\frac{8 \cdot \omega \cdot N \cdot L \cdot P}{\pi \cdot V_{i} \cdot V_{o}} \leq 1 .
$$

\section{B. Dynamic operation mode}

During the fuel cell start-up period, supercapacitor tank is discharged to supply the energy that load required. The Vc will decrease from $V_{\text {cnormal }}$ to $V_{\text {cstable }}$, and $V_{\text {cnormal }}=2 V_{\text {cstable. }}$. To extend the ZVS range, in this mode, phase-shift with duty ratio control is used (Mode II). The definition of the duty ratio and typical operating waveforms are shown in Fig. 4. Because of the close-loop control, the output voltage is assume to be constant; thus the $\mathrm{HV}$ side operates in the $D=0.5$, square-wave mode. Input voltage varies, so we add the duty ratio in the primary side, and calculate the duty cycle as:

$$
d=\frac{D}{2 \pi}=\frac{V_{\text {cstable }}}{2 V_{i}}=\frac{V_{o}}{4 N V_{i}} .
$$

According to (9), the duty ratio is inversely proportional to the voltage. If the $V_{i}$ equals to $V_{\text {cstable }}$, then $D=0.5$ and circuit translates to Mode I.

With reference to Fig. 4, the power flow and peak current in this mode are calculated, respectively, under $0.25<D<0.5$, to be as:

$$
\begin{aligned}
& P=\frac{V_{i} V_{o}[\delta(\pi-\delta)+(D-\delta) \cdot(\pi+\delta-D)]}{4 \pi N \omega L} . \\
& I_{\text {peakl }}=\frac{2 V_{o} \delta+V_{o} \pi+2 D\left(N V_{i}-V_{o}\right)}{4 \omega N L}>I_{\text {peakl }} .
\end{aligned}
$$

From (10), it is shown that due to the duty ratio control, under $\delta<\pi D$, more power transferred at given phase shift and circuit parameters comparing with that under only phase shift. On other hand, the peak current value is higher that that in Mode I, and it causes the high RMS value to lead bad 


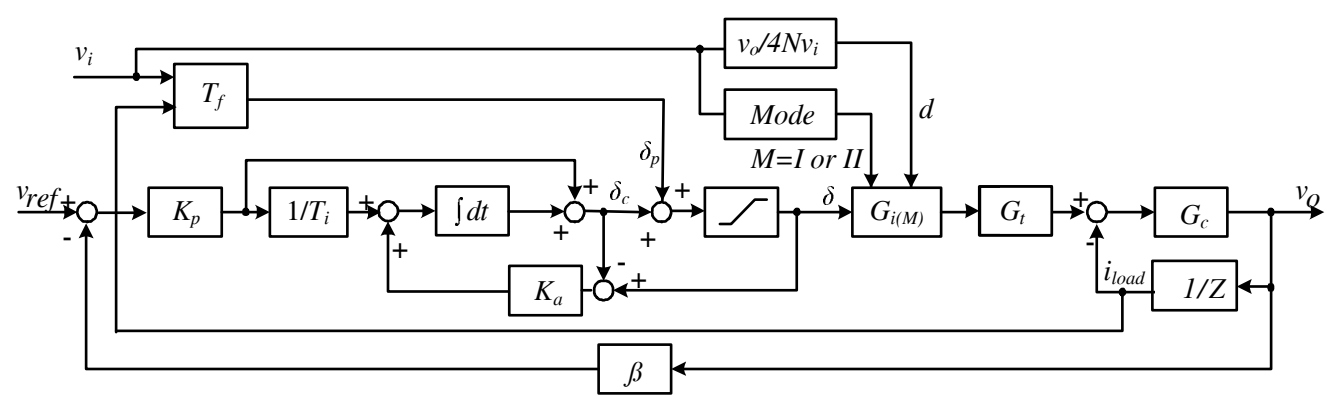

Figure 7. Block diagram of the closed-loop control scheme

efficiency, so the system is not suitable to work in Mode II for long period.

The system can realize the seamless conversion between the different modes. But as mentioned above, the load disturbance will cause $v_{i}$ changed and lead system to Mode II where peak current is high. To avoid the chattering between the two modes, a mode selection method with the hysteresis comparator is applied, shown in Fig. 5.

\section{Parameters}

From (7), the control variable, $\delta$, is non-linear relationship with the output power or the output voltage. So it is more complicated to choose the parameters.

According to the paper [19], the phase shift should be restricted to less than 0.275 p.u. (1 p.u. represents 180 degrees) to avoid large reactive power circulating within power stage which causes large loss. That will limit the power could be delivered as well as the parameters: the inductance of $L$, switching frequency and turns ratio $n$.

The ZVS region and boundaries are analyzed in [4], [6]. At the rated load, the all switches could be operated under the ZVS condition. But the high RMS value and peak currents on the primary side of the power converter represented the big challenge and limited the efficiency in system design. The RMS value of the current in the switch in primary side is as:

$$
I_{s}=\sqrt{2} \cdot \sqrt{\frac{I_{p 1}^{2}+I_{p 1} \cdot I_{p 2}+I_{p 2}^{2}}{3}+\frac{\delta\left(3\left(I_{p 2}-I_{p 1}\right)^{2}+4 I_{p 1} I_{p 2}\right)}{3 \pi}} .
$$

To optimized design to limit the value in (12), the inductor and turns ratio are carefully selected. Inductor value directly affects the power delivery capability and turns ratio affects the phaseshift angle, which affects the reactive power and power losses. For given output voltage and power, the Fig. 6(a) shows the relationship of the $I_{s}$, RMS value of the current in switch in primary side, $N$ and $L$. In the range of $N$ and $L$ being both smaller, the $I_{s}$ changes dramatically. Select the parameters as: $n=4.5, L=9 u H$ at $V_{i}=50 \mathrm{~V}, V_{o}=400 \mathrm{~V}, P_{o}=1 \mathrm{~kW}$. Because the $V_{i}$ is changed during the fuel cell stack start-up period and instantaneous load disturbance, the relationship of input voltage variation and $I_{s}$ is shown in Fig. 6(b). We can find that when operate the converter based on the parameters we have chosen, the $I_{s}$ is not very sensitive to input voltage variation when the input voltage is $50 \mathrm{~V}$ around, but when the input voltage is near to $100 \mathrm{~V}$, the $I_{s}$ will be bigger and we should change the operation mode there.

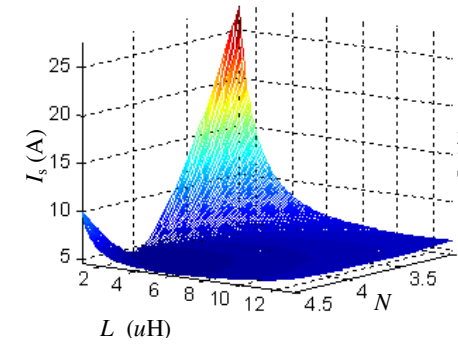

(a)

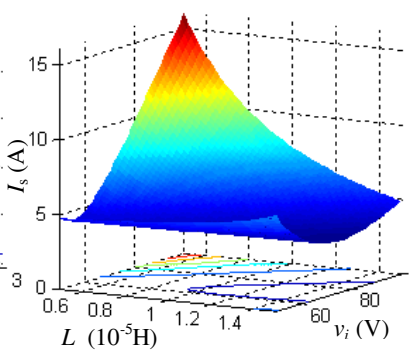

(b)
Figure 6. Relationships between the key parameters
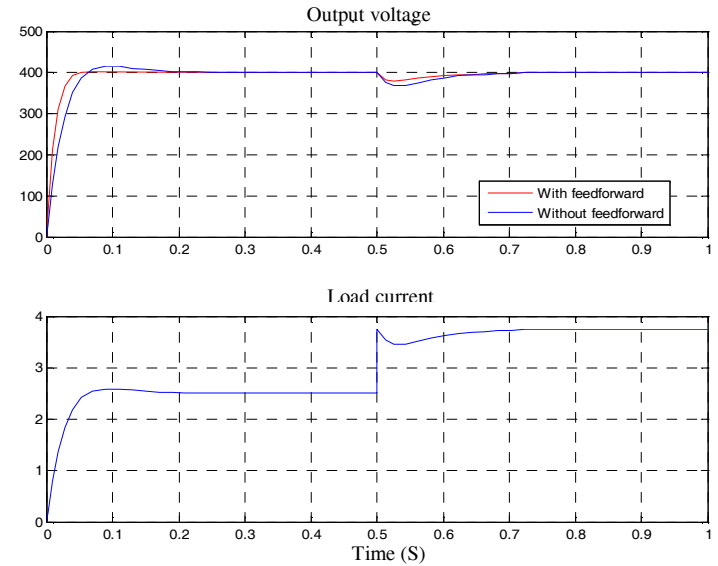

Figure 8. Simulation results: control with load current feedback (red one) and without load current feedback (blue one).

Depending on the $L$, the values of $C_{1}$ and $C_{2}$, and the ripple voltage on the output capacitors is expressed as:

$$
\begin{gathered}
C_{1,2} \geq \frac{1}{100 \omega^{2} L} . \\
\Delta U_{c 1,2}=\frac{1}{2 C_{1,2}} \int_{0}^{\frac{\delta_{\max }}{2 \omega}}\left(\frac{4 \omega \cdot I_{p 2}}{\delta_{\max }} \cdot t\right) \cdot d t=\frac{I_{p 2} \cdot \delta_{\max }}{4 \omega C_{1,2}} .
\end{gathered}
$$

\section{Starting procedure}

At the system starting stage, at that time the $V_{o}=0$, from (2) and (3), an inrush would flow and cause the inductor saturation. Soft-start or pre-charge has been discussed in many papers [5]. A simple one is proposed based on the modulation 
scheme used in this paper. In (11), when phase-shift angle equals to zero, the LV side switches are under duty cycle control and $\mathrm{HV}$ side switches are under synchronous rectifying operation, so at the first pulse of $V_{i}$ with the duty cycle of $d$, the peak value of $i_{1}, I_{1 f p}$, is expressed as:

$$
I_{1 f p}=\frac{V i}{\omega L} \cdot d \text {. }
$$

It is evident that we can limit the inrush current through suppression of the duty cycle.

\section{SyStem CONTROL}

\section{A. Closed loop controller design}

Equation (7) and (11) indicate that $V_{o}$ is not proportional to the phase-shift angle directly, but under $\delta<0.275$ p.u. it is linear control region of the phase-shift for the converter, approximately. Since the voltage on the supercapacitor varies very slow comparing with the switching frequency, so it a very slow disturbance to the whole system and under the closed-loop operation, in the Mode II, the $d$ is inversely proportional to the supercapacitor voltage, so $d$ can also be viewed as a very slow disturbance.

The system's control diagram is shown in Fig. 7. A load current predictive PID control with anti-windup protection is used in the system. In the scheme, the $v_{i}$ and $i_{o}$ are measured. It is necessary to measure $v_{i}$ to realize the mode selection and avoid over-voltage and under-voltage. For the load sensor, it is useful to monitor over-current and output power, to limit the power from fuel cells.

As $I_{o}=I_{\text {load }}$, so the $I_{\text {load }}$ is considered as the first perturbation value of the system to the output of the PI controller through the $T_{f}$, and $v_{i}$, the voltage on the supercapacitor stacks, is considered as a very slow disturbance to the system, where $T_{f}$ contains the equation (7) but in this paper the function obtained through the measured results on the prototype because of loss in the system. The anti-windup protection is helpful to prevent the saturation of the integrator to improve the stability of the system, where $K_{a}$ should be in the same order with $K_{p} / \tau$.

Added the small-signal disturbance in (9), the small-signal transfer functions are:

$$
\begin{gathered}
G_{i(I)}=\frac{\hat{I}_{o}}{\hat{\delta}}=\frac{V_{i}(\pi-2 \delta)}{4 \pi \omega N L} \\
G_{t}=\frac{1}{1+s T_{d}} \\
G_{c}=\frac{R_{c}}{1+s R_{c} C_{1}}
\end{gathered}
$$

where $T_{d}=\frac{1}{2} T_{\text {sample }}+T_{m}+T_{r}$, defined in [14], and $T_{\text {sample }}$ is the sampling time of the processor system. The time delay $T_{m}$ is the delay time caused by the modulator and equal to $\pi / \omega$, and $T_{r}$ contains the remaining delay times. We can get the $R_{c}$ by paralleled discharging resistor in $C_{1}$ and the resistor of virtual load. With the same method, $G_{i(I I)}$ is derived from (10), by adding the small-signal disturbance with on-line calculated duty cycle.

The simulation results based on Matlab are shown in Fig. 8. The simulation parameters are: $V_{\mathrm{i}}=50 \mathrm{~V}, V_{\mathrm{o}}=400 \mathrm{~V}$, and the output power set up from $1 \mathrm{~kW}$ to $1.5 \mathrm{~kW}$ at 0.5 second with the $K_{p}=3.05 \times 10^{-3} \mathrm{rad} / \mathrm{V}, K_{i}=125 \times 10^{-3} \mathrm{rad} / \mathrm{V}$. Adding the load current feedback control will improve the system dynamic performance.

\section{PROTOTYPE AND EXPERIMENT}

In order to verify the feasibility and performance of the converter, a laboratory prototype is built and tested. Circuit parameters and components used of the converter are listed in Table II.

In Fig. 9 and Fig. 10, the waveforms comparison shows the validity of the parameters optimization design. Under the rated input and output voltages, the inductor current is flat after choosing reasonable inductance and transformer turn ratio.

In Fig. 11 and Fig. 12, the gate drive signals and the corresponding drain-source voltage waveforms show that the all switches in primary side or secondary side can realize ZVS on under rated power.

Waveforms in Mode II, are shown in Fig. 13, under $V_{\mathrm{o}}=400 \mathrm{~V}, \delta=28.8^{\circ}$ and $d=0.43$. In this mode, $v_{\mathrm{AB}}$ shows the waveform with three voltage-levels.

Under the light-load condition, the ZVS on is hard to be realized for the switches, especially for the high voltage side switches. We could find that in Fig. 14, when $Q_{1}$ turn on, the secondary side current is about zero, so the $Q_{1}$ is under hardswitching.

TABLE II

PROTOTYPE PARAMETERS AND COMPONENTS

\begin{tabular}{|l|l|}
\hline Switches of the primary side & STW34NB20 (200V/34A) \\
\hline Switches of secondary side & IRFP450LC $(500 \mathrm{~V} / 14 \mathrm{~A})$ \\
\hline Output DC capacitor $\left(C_{1}, C_{2}\right)$ & $470 \mathrm{uF} / 350 \mathrm{~V}$ \\
\hline Transformer core material & Ferrite PC40 \\
\hline Transformer turns & $6: 26$ \\
\hline Transformer leakage inductance & $1 \mathrm{uH}$ \\
\hline Auxiliary inductor & $9 \mathrm{uH}$ \\
\hline Auxiliary transformer core material & Ferrite N27 \\
\hline Snubber film capacitor & $1 \mathrm{nF}$ \\
\hline Switching frequency & $20 \mathrm{kHz}$ \\
\hline Digital controller & TI TMS320F2808 DSP \\
\hline
\end{tabular}

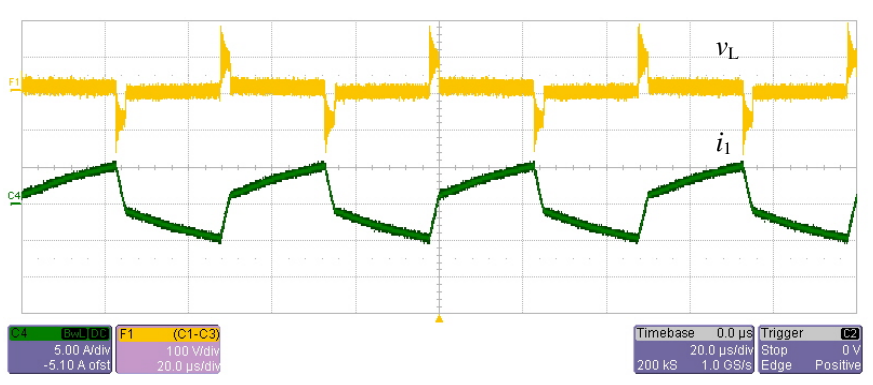

Figure 9. Waveforms before optimization design. 


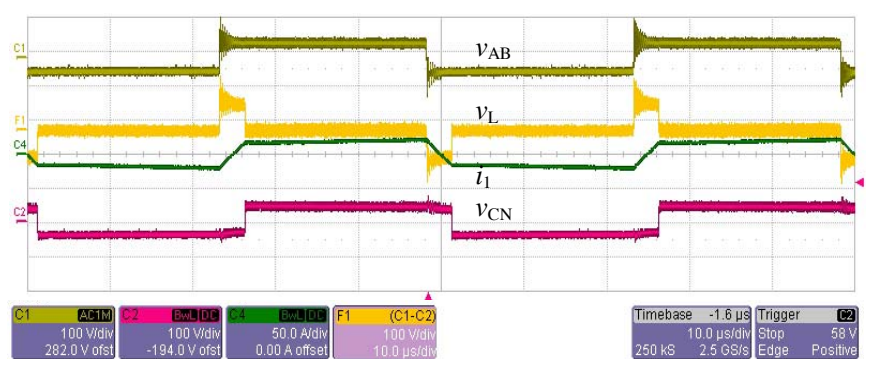

Figure 10. Waveforms after optimization design.

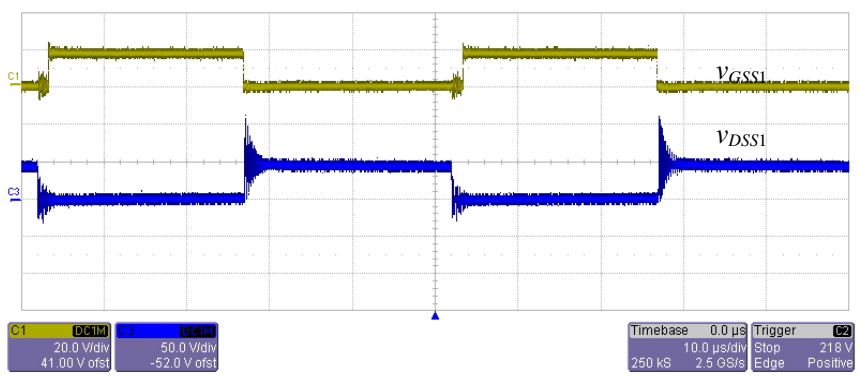

Figure 11. Waveforms of $S_{1}$ under ZVS

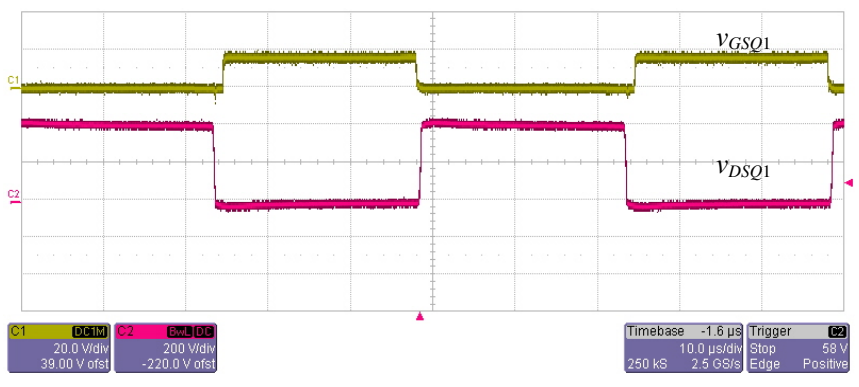

Figure 12. Waveforms of $Q_{1}$ under ZVS.

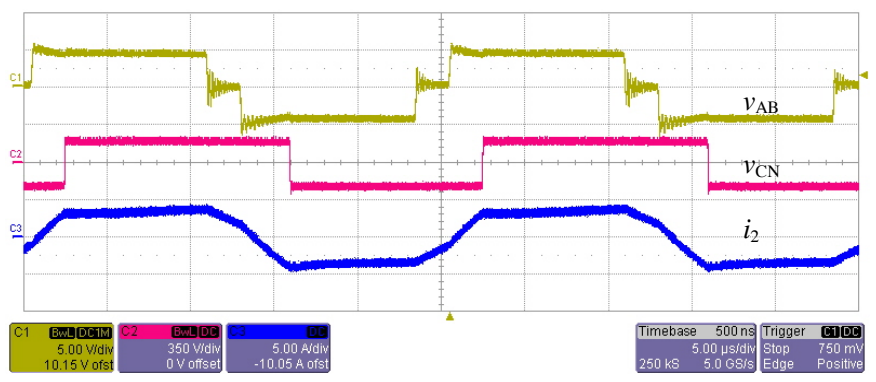

Figure 13. Waveforms of converter operating in Mode II.

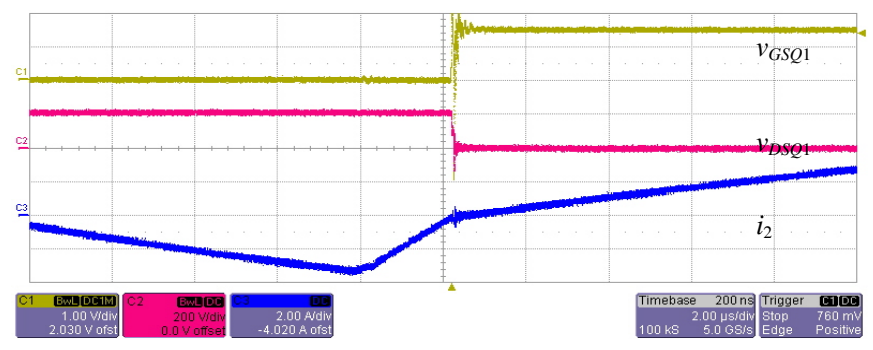

Figure 14. Waveforms of the $Q_{1}$ under hard-switching in Mode I.

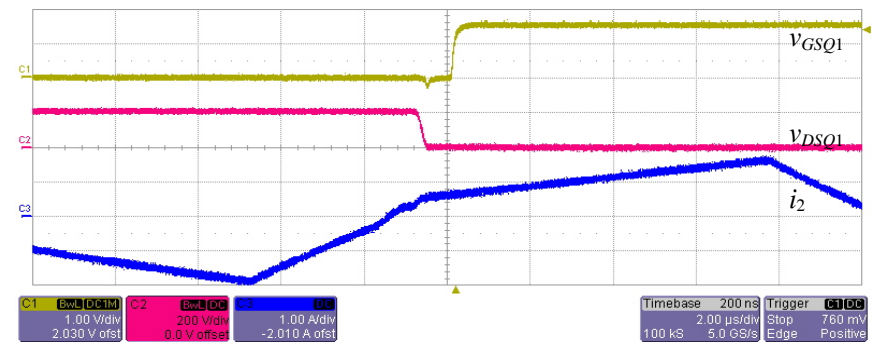

Figure 15. Waveforms of the $Q_{1}$ under ZVS in Mode II.

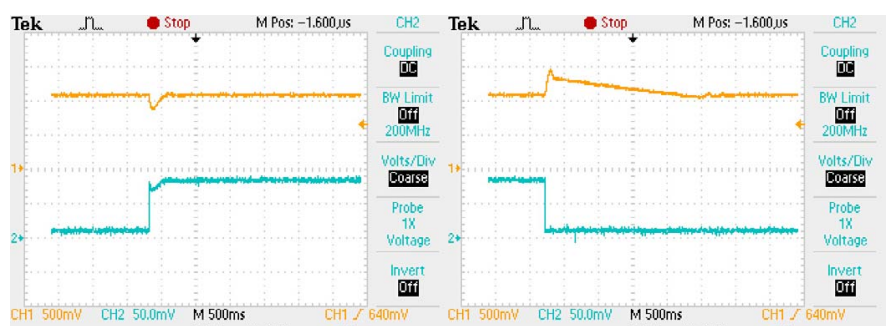

(a)

(b)

Figure 16. The system dynamic responses under load sudden change: (a) from $0.2 \mathrm{~A}$ to $1.8 \mathrm{~A}$; (b) from $1.8 \mathrm{~A}$ to $0.2 \mathrm{~A}$

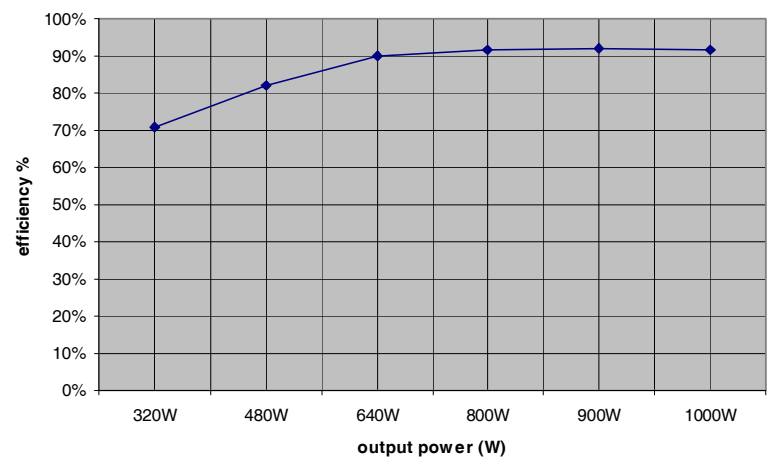

Figure 17. The efficiency curve.

Then add the duty control, at same output power, it can realize ZVS again, shown in Fig. 15.

In Fig. 16, the dynamic response shows the effect of the closed-loop control scheme is receivable.

The maximum efficiency of the converter shown in Fig. 17 is about $91 \%$. At idle mode, the idle loss is smaller than $15 \mathrm{~W}$. Because of the limitation of phase-shift angle by practical circuits, under the rated input and output voltages, converter can not operate without load. Under rated output power condition, the loss mainly causes by the high RMS current value in the primary side, so the paralleled Mosfet to decrease the on-resistance of the switch should be used to improve the efficiency.

\section{CONCLUSION}

This paper has addressed the bi-directional isolated DC/DC converter to be used in the fuel cell and supercapacitor hybrid 
system. With the analysis of the characteristics of the converter, mode conversion scheme should be used in the system to extend the ZVS range and improve the system efficiency in terms of the different input voltage levels. And the phase-shift with duty control can also to be used to limit the inrush current during the start-up stage. Based on the simulation and experimental results, the closed-loop control scheme can realize the converter output stable and dynamic response well, but the parameters in controller should be analyzed and designed in depth to improve the system performance and stability in the future. In general, the results from the prototype in lab controlled by DSP clarify the validity of the analysis and design.

\section{REFERENCES}

[1] Josep M. Guerrero, "Uninterruptible power supply systems provide protection," in: IEEE Industrial Electronics Magazine, 2007, 1 (1), p. 28-38.

[2] Yu X., Starke, M.R., Tolbert, L.M., Ozpineci B., "Fuel cell power conditioning for electric power applications: a summary," IET Electric Power Applications, vol. 1, pp. 643-656, 2007.

[3] R. W. De Doncker, D. M. Divan, and M. H. Kheraluwala, "A three- phase soft-switched high-power desity $\mathrm{dc} / \mathrm{dc}$ converter for high power applications," IEEE Transactions on Industry Application, vol. 27, no. 1, pp.63-67, 1991.

[4] M. H. Kheraluwala, R. W. Gascoigne, D. M. Divan and E. D. Baumann, "Performance characterization of a high-power dual active bridge dc-dc converter," IEEE Transactions on Industry Application, vol. 28, no.6, pp. 1294-1301, Nov./Dec. 1992.

[5] H. L. Chan, K. W. E. Cheng and D. Sutanto, "Phase-shift controlled DCDC converter with bi-directional power flow," IEE Proc.-Electr. Power Appl., vol. 148, no. 2, Mar. 2001, pp.193-201.

[6] S. Inoue and H. Akagi, "A Bidirectional DC-DC Converter for an Energy Storage System With Galvanic Isolation," IEEE Transactions on Power Electronics, vol. 22, no. 6, pp. 2299-2306, 2007.
[7] F. Z. Peng, H. Li, G. J. Su, and J. S. Lawler, "A new ZVS bi-directional dc-dc converter for fuel cell and battery applications," IEEE Transactions on Power Electronics, vol. 19, no. 1, pp. 54-65, 2004.

[8] H. Li and F. Z. Peng, "Modeling of a new zvs bi-directional dc-dc converter," IEEE Transactions on Aerospace and Electronic Systems, vol. 40, pp. 272-283, January 2004.

[9] D. Liu and H. Li, "Design and implementation of a DSP based digital controller for a dual half bridge isolated bi-directional dc-dc converter," Twenty-First Annual IEEE Applied Power Electronics Conference and Exposition, APEC2006, pp.

[10] K. Wang, C. Y. Lin, L. Zhu, D. Qu, F. C. Lee, and J. S. Lai, "Bidirectional dc-dc converters for fuel cell systems," IEEE Transactions On Transportation, pp. 47-52, Oct. 1998.

[11] L. Zhu, "A novel soft-commutating isolated boost full-bridge ZVSPWM dc-dc converter for bidirectional high power application," IEEE Transaction on Power Electronics, vol. 21, no. 2, pp. 422-429, Mar. 2006.

[12] J. Wnag, F. Z. Peng, J. Anderson, A. Joseph and R. Buffenbarger, "Low cost fuel cell converter system for residential power generation," IEEE Transactions on Power Electronics, vol. 19, no. 5, pp. 1315-1322, 2004.

[13] H. Tao, Kotsopoulos A., Duarte J.L., Hendrix M.A.M.,"Transformercoupled multiport ZVS bidirectional DC-DC converter with wide input range," IEEE Transactions on Power Electronics, vol. 23, no. 2, pp. 771-781, 2008.

[14] H. Xiao and S. Xie, "A Zvs bidirectional dc-dc converter with phasedshift plus PWM control scheme," IEEE Transactions on Power Electronics, vol. 23, no. 2, pp. 813-823, Mar. 2008.

[15] N. Schibli, "Symmetrical multilevel converters with two quadrant DCDC feeding." EPFL, PhD Thesis, no.2220, 2000.

[16] F. Krismer, S. Round, and J. W. Kolar, "Performance optimization of a high current dual active bridge with a wide operating voltage range," The 37th IEEE Power Electronics Specialists Conference, PESC2006, pp. 1-7, June 2006

[17] D. Xu, C. Zhao and H. Fan, "A PWM plus phase-shift control bidirectional DC-DC converter" IEEE Transactions on Power Electronics, vol. 19, no. 3, pp.666-675, Mar. 2004.

[18] G. D. Demetriades, "On small-signal analysis and control of the single and the dual active bridge topologies," KTH, Doctoral thesis, 2005.

[19] M. N. Gitaua, G. Ebersohna and J. G. Kettleboroughb, "Power processor for interfacing battery storage system to $725 \mathrm{v}$ dc bus," Energy Conversion and Management, vol. 48, pp. 871-881, Mar. 2007. 